Research Article

\title{
Design of New High Step-Up DC-DC Converter Topology for Solar PV Applications
}

\author{
Shanthi Thangavelu $\mathbb{D}^{1}$ and Prabha Umapathy $\mathbb{D}^{2}$ \\ ${ }^{1}$ Electrical and Electronics Engineering Department, Kumaraguru College of Technology, Coimbatore, Tamil Nadu, India \\ ${ }^{2}$ Electrical and Electronics Engineering Department, Dr. NGP Institute of Technology, Coimbatore, Tamil Nadu, India
}

Correspondence should be addressed to Shanthi Thangavelu; shanthits@gmail.com

Received 9 October 2021; Revised 29 October 2021; Accepted 27 November 2021; Published 16 December 2021

Academic Editor: Huiqing Wen

Copyright () 2021 Shanthi Thangavelu and Prabha Umapathy. This is an open access article distributed under the Creative Commons Attribution License, which permits unrestricted use, distribution, and reproduction in any medium, provided the original work is properly cited.

\begin{abstract}
A new topology for high step-up nonisolated DC-DC converter for solar PV applications is presented in this paper. The proposed high-voltage gain converter topology has many advantages like low-voltage stress on the switches, high gain with low duty ratio, and a continuous input current. The analytical waveforms of the proposed converter are presented in continuous and discontinuous modes of operation. Voltage stress analysis is conducted. The voltage gain and efficiency of the converter in presence of parasitic elements are also derived. Performance comparison of the proposed high-gain converter topology with the recently reported high-gain converter topologies is presented. Validation of theoretical analysis is done through the test results obtained from the simulation of the proposed converter. For the maximum duty ratio of $80 \%$, the output voltage of $670 \mathrm{~V}$ is observed, and the voltage gain obtained is 14. Comparison of theoretical and simulation results is presented which validates the performance of the proposed converter.
\end{abstract}

\section{Introduction}

The application of renewable energy sources for day-to-day life is increasing widely. This is due to clean and green nature of energy produced by renewable energy sources. Among the renewable energy sources, solar energy is most promising because of its pollution-free nature. But the output voltage obtained from the solar photovoltaic (PV) panels is very low, and therefore, it cannot be connected to highvoltage load or grid directly. Therefore, a dc-dc conversion stage with high gain is required to interface the solar PV with high-voltage load or grid. Many high-gain DC-DC converters were reported in the last one decade. But the design improvement of these high-gain DC-DC converters with respect to increased voltage gain, component reduction, increased efficiency, and reduced losses is still being reported by many researchers. These high-gain DC-DC converters also find their applications in fuel cells, electric vehicles, battery energy storage, automotive industries, and uninterrupted power supplies [1-4].
Basically, there are two types of DC-DC converters, namely, nonisolated and isolated DC-DC converters. Isolated DC-DC converters mainly used in high power applications. But the presence of transformers increased the converter size. The conventional boost converters are used in the earlier stages for stepping up the voltage, but the limitation is the high-voltage stress on the switch, and hence, high-rating switch is needed.

An interleaved high step-up boost converter was proposed in [5] for PV applications. This converter provides a high efficiency and high step-up gain, but this converter uses more number of components which leads to increase in losses at higher loads due to the effect of parasitic elements. Converters reported in [6,7] employed a switched capacitor structures to achieve a high step-up conversion ratio. Even though this technique provides a high conversion ratio, the stability of the converter reduces due to the presence of impulse current.

A nonisolated high step-up DC-DC converter with single-inductor energy storage cell based switched capacitor 
configuration was proposed in [8]. This configuration was derived from the basic boost-, buck-boost-, and type II boost/buck-boost-based converters. This converter integrates the merits of high gain of switched capacitor (SC) converter and high output voltage regulation of switching mode DC-DC converter.

A high-gain nonisolated DC-DC converter for DC microgrids was proposed in [9]. This converter used voltage multiplier cell and hybrid switched-capacitor technique. Here, the switches are operated with a combined duty ratio of maximum 95\% to achieve the gain. Clamping circuits used increase the circuit complexity. A nonisolated converter with automatic output voltage balancing was reported in [10]. High step-up DC-DC converter with active switched LC-network was proposed in [11]. This converter uses an active switched capacitor and inductor network. Inputparallel output-series dc-dc boost converter was reported in [12]. Here, the input current ripple is reduced by adopting interleaved structure. Though the gain and efficiency are more, the number of components used are more which increases the size and cost.

A dc-dc multilevel boost converter which combines the boost converter and a switched capacitor was reported in [13]. This converter operates with a continuous input current and high switching frequency. Cascaded structure for n-stage conversion is also discussed. A nonisolated boost DC-DC converter based on voltage-lift technique with a single switch was reported in [14]. This technique is based on energy storage elements inductor and capacitor. But the increase in number of components makes the system complex. A new family of single-switch three-diode dc-dc pulse width-modulated (PWM) converters operating at constant frequency and constant duty cycle was discussed in [15]. There is a less-voltage stress on the diodes and decreased switch and conduction losses. Voltage multipliers can be integrated to increase the voltage gain.

A transformerless inverter with active power decoupling was reported in [16]. An extended duty ratio (EDR) boost is implemented as the high-gain dc-dc stage. A high step-up DC-DC converter with active switched inductor and passive switched capacitor networks was proposed in [17]. Here, voltage stresses are minimal. Extendable nonisolated highgain DC-DC converter based on active-passive inductor cells was proposed in [18]. The principle of operation is based on parallel charging and series discharging of the inductors. This uses more number of components; hence, more complex is the system. Recently, coupled inductors find their applications in DC-DC converters to obtain a high-voltage gain. This leads to a compact system because of only one inductor [19-23]. A single-switch buck-boost DC/DC converter [24], SEPIC-based single switch buck/boost DC/DC converter with continuous input current [25], and a singleswitch quadratic buck/boost DC/DC converter with continuous input and output current [26] were also reported. In all these single-switch converters, the number of capacitors, inductors, and diodes are more. The converter reported in [27] used switched inductor concept and uses two switches. [29] reports the quasiswitched converter which produces high gain with the low duty ratio. An interleaved converter with inverting capability is reported in [28]; even though the gain is high, the total components required is more. Therefore, the need for a high-gain transformerless DCDC converter with less number of components arises to enhance the dc-link voltage.

Figure 1 shows the application of high-gain DC-DC converter in grid-connected solar PV system. In this paper, a new topology for a high-gain DC-DC converter is introduced. The proposed high-gain DC-DC converter uses three switches. The operating principle of the proposed converter in continuous conduction mode (CCM) and discontinuous conduction mode (DCM) are explained, and the boundary conditions are derived. Performance comparison of the proposed high-gain converter topology and the other recent high-gain topologies is made and analyzed. Simulink model of the proposed converter is developed, and the results were presented and discussed in detail.

\section{Principle of Operation of Proposed Converter}

A high-gain DC-DC converter with crossconnected capacitors is proposed in this paper. Figure 2 shows the circuit configuration of the proposed converter. The proposed converter consists of three switches $S_{1}, S_{2}$, and $S_{3}$, two inductors $\mathrm{L}_{1}$ and $\mathrm{L}_{2}$, four diodes $\mathrm{D}_{1}, \mathrm{D}_{2}, \mathrm{D}_{3}$, and $\mathrm{D}_{4}$, and three capacitors $\mathrm{C}_{1}, \mathrm{C}_{2}$, and $\mathrm{C}_{o}$. The duty ratio of $\mathrm{S}_{1}$ and $\mathrm{S}_{3}$ is $d_{1}$ and that of $\mathrm{S}_{2}$ is $d_{2}$. The crossconnected capacitor structure used at the end of the converter circuit will double the output voltage; hence, increase in voltage gain is achieved in the proposed converter circuit. Depending on the switching operations of the switches $S_{1}, S_{2}$, and $S_{3}$, there are three modes of operations present in the proposed converter during continuous conduction mode (CCM).

Mode 1: in this mode, all the three switches $\mathrm{S}_{1}, \mathrm{~S}_{2}$, and $\mathrm{S}_{3}$ are simultaneously turned on at $t_{0}$. The equivalent circuit shown in Figure 3(a) for this mode shows the current path clearly. Here, the inductors $\mathrm{L}_{1}$ and $\mathrm{L}_{2}$ are parallelly charged from the input source $V_{i}$. The diodes $\mathrm{D}_{1}, \mathrm{D}_{2}$, and $\mathrm{D}_{3}$ are reverse biased. Diode $\mathrm{D}_{4}$ is forward biased. The load current is supplied by the capacitors $C_{1}$ and $C_{2}$. The voltage across both the inductors $\mathrm{L}_{1}$ and $\mathrm{L}_{2}$ is equal to the input source voltage.

Mode 2: when the switches $S_{1}$ and $S_{3}$ are turned off at $t_{1}$, this mode of operation is established. Switch $S_{2}$ still conducts. Figure 3(b) shows the equivalent circuit for this mode. Here, the diodes $D_{1}$ and $D_{4}$ are forward biased, and other diodes are reverse biased. Both the inductors will get connected in series and are charged from the input source. The voltage across each inductor is $V_{i} / 2$. The output voltage $V_{\mathrm{o}}$ is equal to the sum of $V_{\mathrm{C} 1}$ and $V_{\mathrm{C} 2}$.

Mode 3: this mode of operation is established when the switch $\mathrm{S}_{2}$ is turned off at $t_{2}$. Equivalent circuit for this mode is shown in Figure 3(c). Diode $\mathrm{D}_{4}$ is reverse biased, and the other diodes are forward biased. The inductors will discharge the stored energy to the load with a voltage of $\left(2 V_{i}\right.$ $\left.-V_{\mathrm{o}}\right) / 4$.

From the analytical waveforms in Figure 4(a), the expression for voltage gain of the proposed converter in 


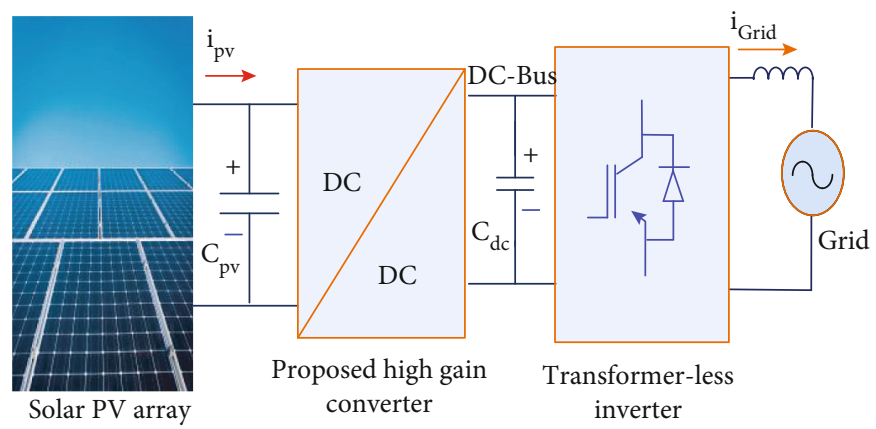

Figure 1: A high-voltage gain DC-DC converter in grid tied solar PV application.

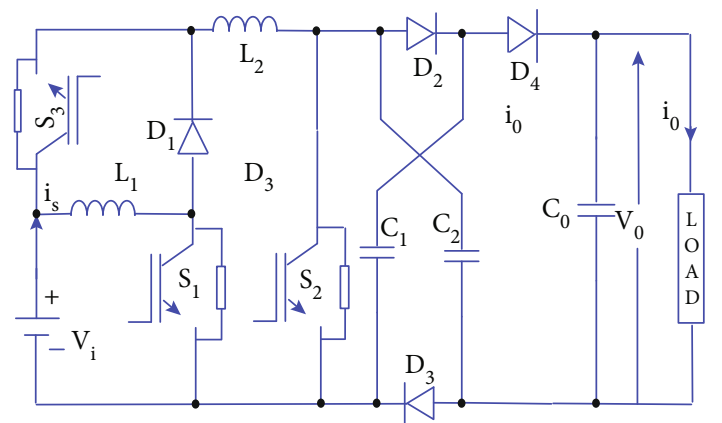

Figure 2: Circuit diagram of proposed high-gain DC-DC converter.

CCM is obtained. By applying the volt-second balance principle for the inductor $\mathrm{L}_{1}$, the voltage gain expression is derived as

$$
M_{\mathrm{CCM}}=\frac{V_{o}}{V_{i}}=2 \frac{1+d_{1}}{1-d_{2}} .
$$

\section{Performance Analysis of Proposed Converter}

3.1. DCM Operation. The proposed converter operates in four modes for the DCM. Mode 1: all the switches $S_{1}, S_{2}$, and $S_{3}$ are turned on at $t_{0}$. The current through the inductors $\mathrm{L}_{1}$ and $\mathrm{L}_{2}$ increases from zero and reaches $I_{\mathrm{L} 1}$ at $t_{1}$. Hence, this operating mode in DCM and CCM is identical. The peak value of inductor current is expressed as

$$
I_{L 1 p k}=\frac{V_{i}}{L} d_{1} T_{s}
$$

Mode 2: here, switches $S_{1}$ and $S_{3}$ are turned off. From the instant $t_{1}$, the current of the inductors further increases and reaches the peak value $I_{\mathrm{L} 2}$ at $t_{2}$. The magnitude of the inductor current during mode 2 operation is expressed as

$$
I_{L 2 p k}=\frac{V_{i}}{2 L}\left(d_{2}-d_{1}\right) T_{s}+I_{L 1 p k}
$$

Mode 3: when $\mathrm{S}_{2}$ is also turned off at $t_{2}$, the inductor current starts decreasing and reaches zero at the instant $d_{x} T_{s}$.
The magnitude of the inductor current in mode 3 operation is expressed as

$$
I_{L 2 p k}=\frac{2 V_{i}-V_{o}}{4 L} d_{x} T_{s}
$$

Mode 4: the equivalent circuit of the proposed converter in this mode is shown in Figure 3(d). Since the inductor current reached zero state, the load current is supplied by the capacitor $C_{\mathrm{o}}$.

From (9) and (10), $d x$ can be calculated as

$$
d_{x}=\frac{2 V_{i}\left(d_{1}+d_{2}\right)}{2 V_{i}-V_{o}} .
$$

The average current of capacitor $C_{\mathrm{o}}$ is expressed as

$$
I_{\mathrm{Co}}=\frac{1}{2} d_{x} I_{L 2}-I_{o}
$$

From Equations (4), (5), and (6) the expression for $I_{\mathrm{Co}}$ can be found as

$$
I_{\mathrm{Co}}=\frac{V_{i}^{2}\left(d_{1}+d_{2}\right)^{2}}{2 V_{i}-V_{C}} \frac{T_{s}}{2 L}-\frac{V_{\mathrm{Co}}}{R} .
$$

Solving Equation (7), the DCM gain of the proposed converter is derived as

$$
M_{\mathrm{DCM}}=1+\sqrt{1+\frac{\left(d_{1}+d_{2}\right)^{2}}{2 \tau_{L}}},
$$

where $\tau_{L}=L / R T_{s}$ is the inductor time constant.

3.2. Boundary Condition Operation. The boundary condition for the proposed converter is determined by considering the CCM and DCM voltage gains are equal.

Therefore,

$$
M_{\mathrm{DCM}}=M_{\mathrm{CCM}}
$$

By substituting Equations (1) and (8) in (9), the time constant of the inductor current at the boundary for the proposed converter is obtained 


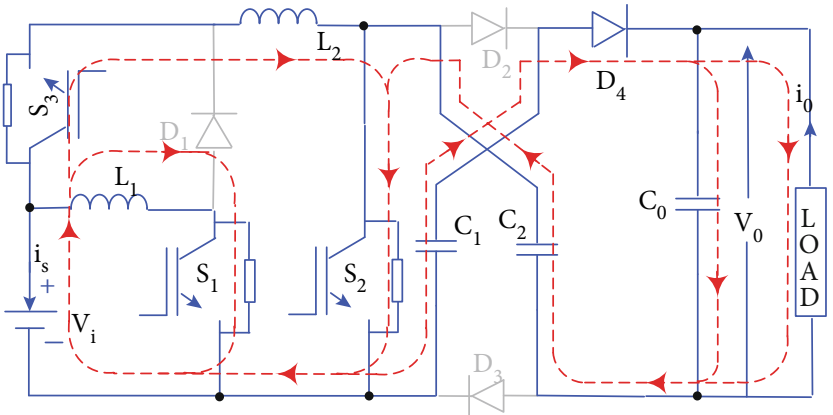

(a)

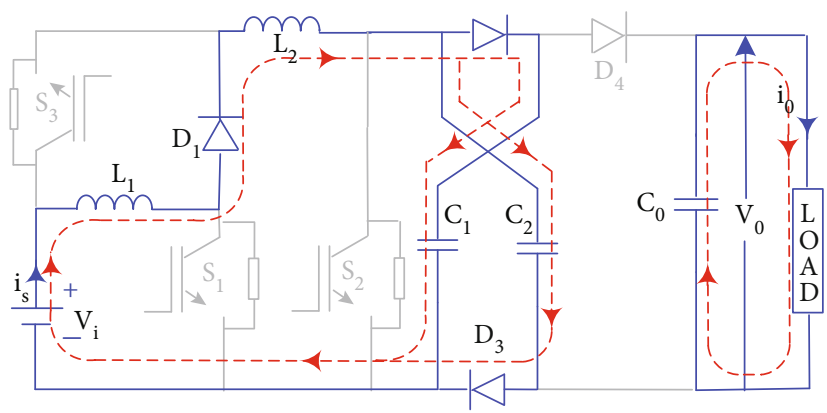

(c)

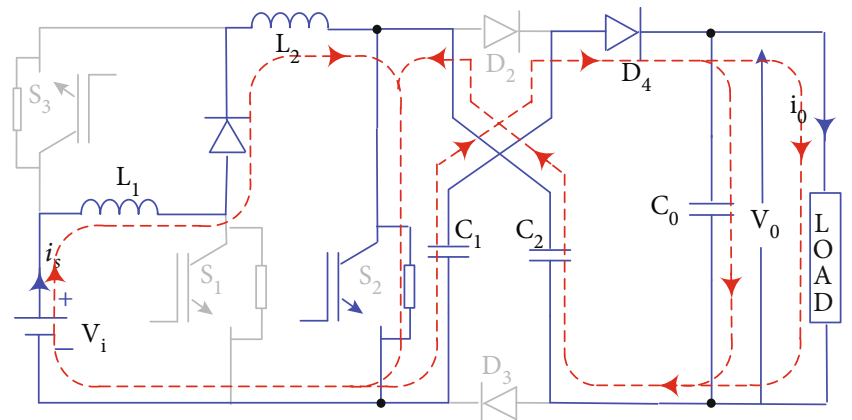

(b)

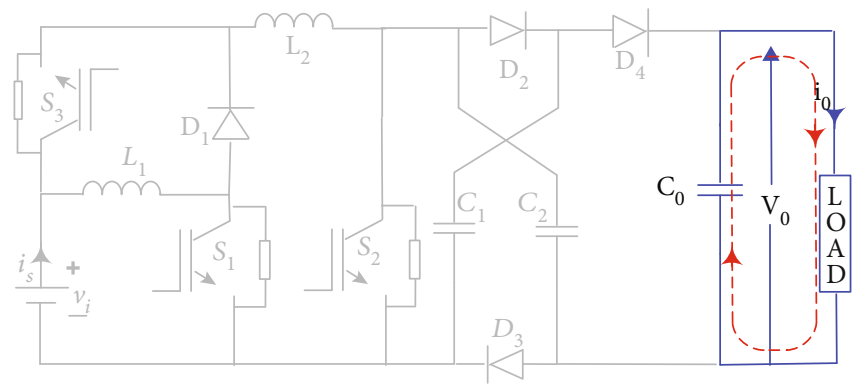

(d)

FIgURE 3: Equivalent circuit of the proposed converter: (a) mode 1, (b) mode 2, (c) mode 3, and (d) mode 4.

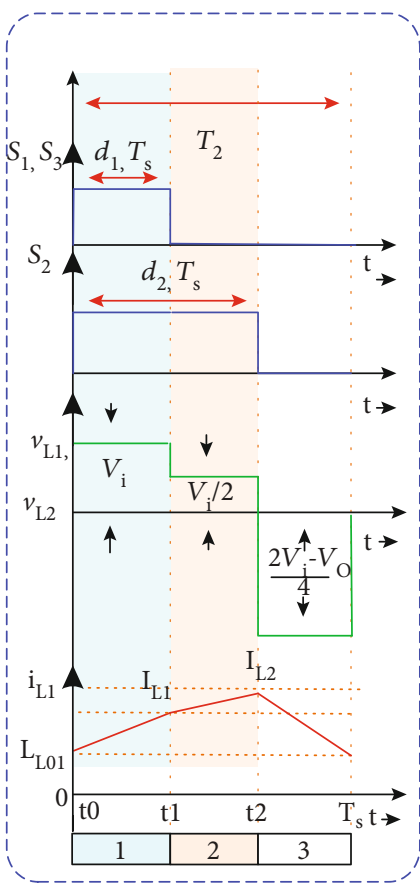

(a)

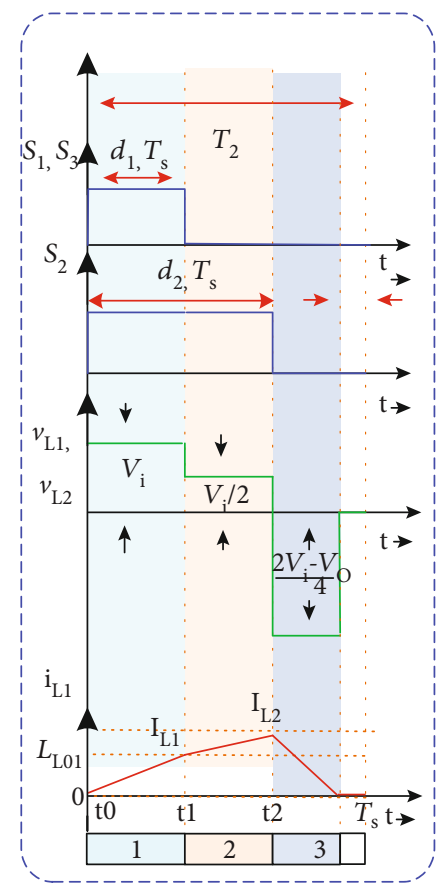

(b)

FIgURE 4: Analytical waveforms of the proposed converter. (a) CCM and (b) DCM.

$$
\tau_{\mathrm{LB}}=\frac{\left(d_{1}+d_{2}\right)\left(1-d_{2}\right)^{2}}{8\left(1+d_{1}\right)} .
$$

The variation of the time constant of the inductor $\tau_{\mathrm{LB}}$ with respect to the duty cycle variation is depicted in
Figure 5. The margins of CCM and DCM operation for the proposed converter are clearly shown.

3.3. Analysis of Dc-Voltage Gain and Converter Efficiency with Parasitic Elements. In this section, the effect of parasitic elements on the voltage gain and the efficiency of the 


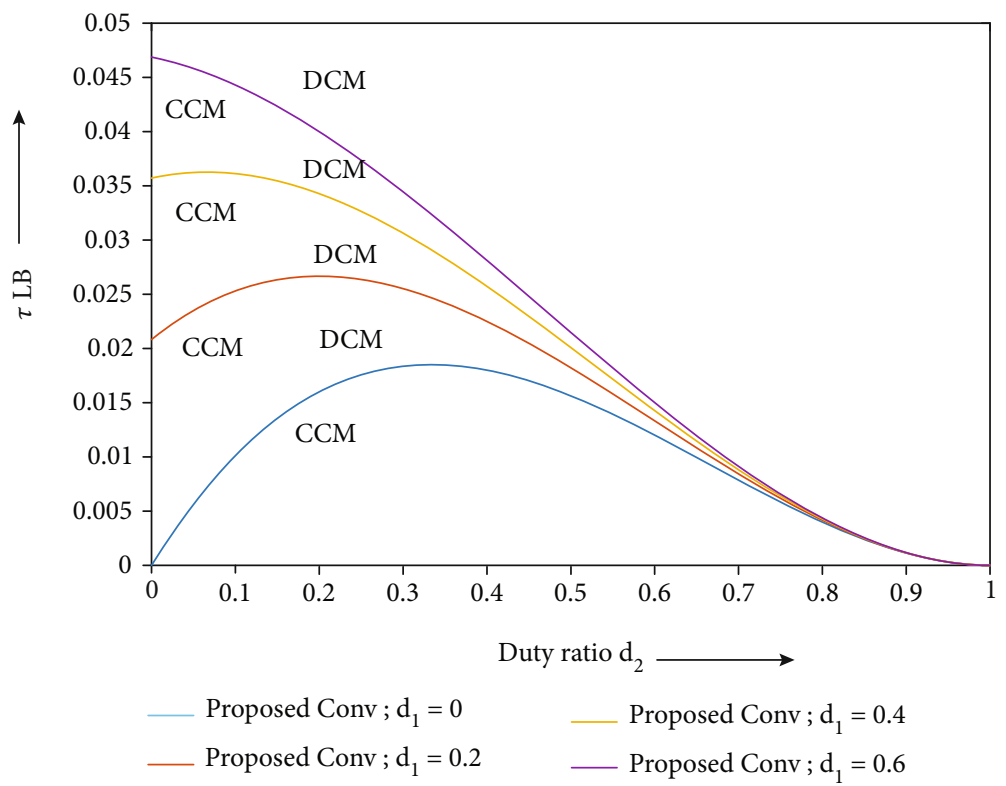

FIGURE 5: Boundaries of the proposed high-gain DC-DC converter.

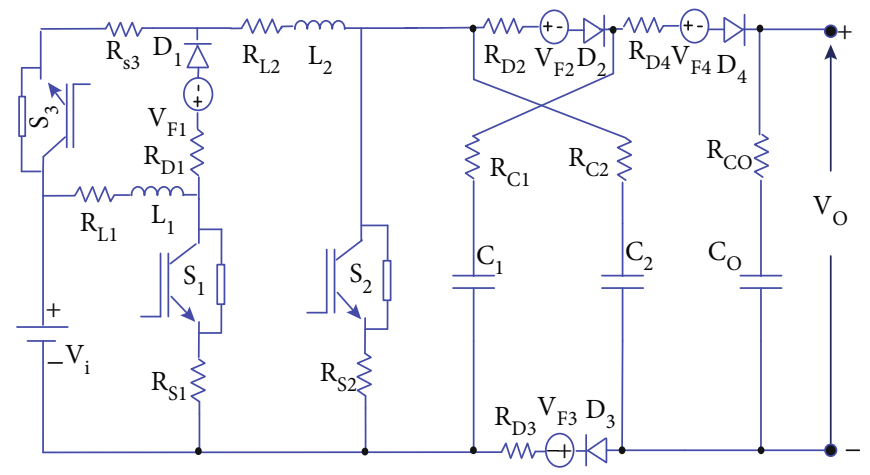

Figure 6: Equivalent circuit of the proposed converter with parasitic elements.

proposed converter is discussed. Figure 6 shows the equivalent circuit of the proposed converter configuration with the presence of parasitic elements. The internal resistances of the inductors $L_{1}$ and $L_{2}$ are represented by $R_{L 1}$ and $R_{L 2}$, respectively. The on-state resistances of the switches $S_{1}, S_{2}$, and $S_{3}$ are represented by $R_{S 1}, R_{S 2}$, and $R_{S 3}$, respectively. The internal resistances and the forward voltages of the diodes $\mathrm{D}_{1}, \mathrm{D}_{2}, \mathrm{D}_{3}$, and $\mathrm{D}_{4}$ are represented as $\mathrm{R}_{\mathrm{D} 1}, \mathrm{R}_{\mathrm{D} 2}$, $\mathrm{R}_{\mathrm{D} 3}$, and $\mathrm{R}_{\mathrm{D} 4}$ and $\mathrm{V}_{\mathrm{F} 1}, \mathrm{~V}_{\mathrm{F} 2}, \mathrm{~V}_{\mathrm{F} 3}$, and $\mathrm{V}_{\mathrm{F} 4}$, respectively. Series equivalent resistances of the capacitors $C_{1}, C_{2}$, and $C_{o}$ are shown as $\mathrm{R}_{\mathrm{C} 1}, \mathrm{R}_{\mathrm{C} 2}$, and $\mathrm{R}_{\mathrm{Co}}$, respectively.

Assuming that the internal resistances of all the diodes are equal to $R_{D}$, series equivalent resistance of all the capacitors are equal to $\mathrm{R}_{\mathrm{C}}$, forward voltages of all the diodes are equal to $\mathrm{V}_{\mathrm{F}}$, on-state resistances of all the switches are equal to $\mathrm{R}_{\mathrm{S}}$, and the internal resistances of both the inductors are equal to $\mathrm{R}_{\mathrm{L}}$ the output voltage expression of the proposed converter with parasitic elements is derived as

$$
V_{o}=\frac{2\left(1+d_{1}\right) V_{i}+2 V_{F}\left(d_{1}+d_{2}-2\right)}{\left(1-d_{2}\right)-A\left(R_{L} / R_{o}\right)-B\left(R_{S} / R_{o}\right)-C\left(R_{D} / R_{o}\right)},
$$

where

$$
\begin{aligned}
A & =\frac{4\left(2 d_{1}^{2}-d_{1} d_{2}+d_{1}-2 d_{2}\right)}{1-d_{2}}, B=4 d_{1}, \text { and } C \\
& =\frac{4\left(d_{1}^{2}+d_{1} d_{2}+d_{1}-d_{2}\right)}{1-d_{2}} .
\end{aligned}
$$

The efficiency of the proposed converter in presence of parasitic elements is expressed as given in

$$
\eta=\eta^{\prime}-\frac{P_{S}}{P_{i}}
$$

where

$\eta^{\prime}=\frac{1+\left(V_{F} / V_{i}\right)\left(\left(d_{1}+d_{2}-2\right) /\left(1+d_{1}\right)\right)}{1-A\left(R_{L} / R_{o}\right)\left(1 /\left(1-d_{2}\right)\right)-B\left(R_{S} / R_{o}\right)\left(1 /\left(1-d_{2}\right)\right)-C\left(R_{D} / R_{o}\right)\left(1 /\left(1-d_{2}\right)\right)}$.

Efficiency of the converter in presence of parasitic elements is plotted and is given in Figure 7. The values of 


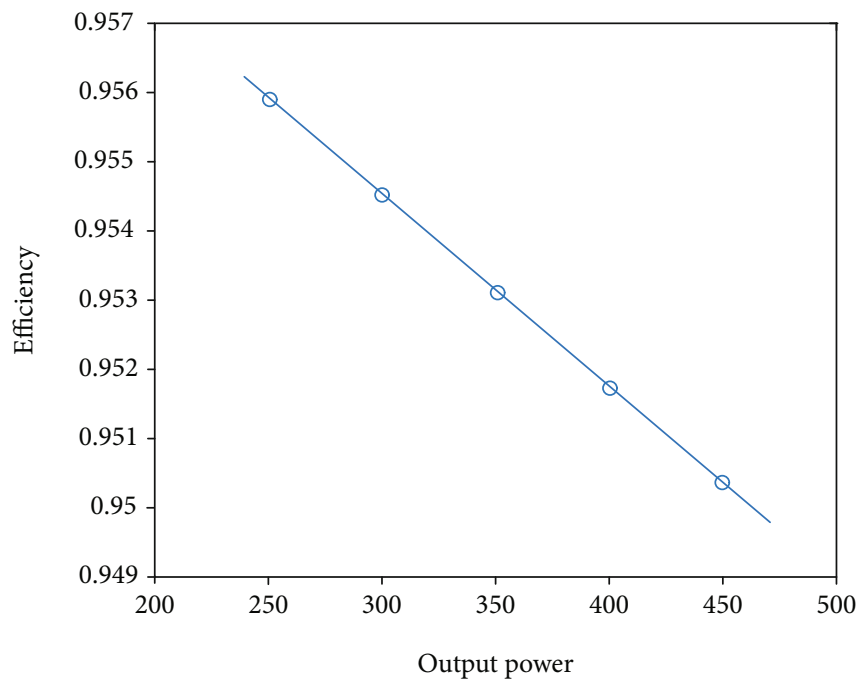

FIGURE 7: Efficiency vs. output power with parasitic elements.

Table 1: Performance comparison of proposed and other existing converter topologies.

\begin{tabular}{|c|c|c|c|c|c|c|c|c|}
\hline Topology & $\begin{array}{l}\text { Proposed } \\
\text { converter }\end{array}$ & $\begin{array}{l}\text { Conventional boost } \\
\text { converter }\end{array}$ & $\begin{array}{c}\text { SEPIC } \\
\text { converter }\end{array}$ & $\begin{array}{c}\text { SC-boost } \\
{[13]}\end{array}$ & $\begin{array}{c}\text { Converter } \\
{[12]}\end{array}$ & $\begin{array}{c}\text { Converter } \\
{[25]}\end{array}$ & $\begin{array}{c}\text { Converter } \\
{[24]}\end{array}$ & $\begin{array}{c}\text { Converter } \\
{[26]}\end{array}$ \\
\hline Voltage gain & $2\left(1+d_{1} / 1-d_{2}\right)$ & $1 / 1-d$ & $d / 1-d$ & $2 / 1-d$ & $2 / 1-d$ & $3 d / 1-d$ & $2 d / 1-d$ & $(d / 1-d)^{2}$ \\
\hline Switches & 3 & 1 & 1 & 1 & 2 & 1 & 1 & 1 \\
\hline Diodes & 4 & 1 & 1 & 3 & 3 & 3 & 2 & 5 \\
\hline Capacitors & 3 & 1 & 2 & 3 & 3 & 6 & 3 & 3 \\
\hline Inductors & 2 & 1 & 2 & 1 & 2 & 4 & 2 & 3 \\
\hline Total device count & 12 & 4 & 6 & 8 & 10 & 14 & 8 & 12 \\
\hline $\begin{array}{l}\text { Voltage stress on } \\
\text { switches }\end{array}$ & $V_{o} / 2$ & $V_{o}$ & $V_{o} / d$ & $V_{o} / 2$ & $V_{o} / 2$ & $V_{o} / 3 d$ & $V_{o} / 2 d$ & $V_{o} / d^{2}$ \\
\hline $\begin{array}{l}\text { Continuous input } \\
\text { current }\end{array}$ & Yes & Yes & Yes & Yes & Yes & Yes & No & Yes \\
\hline
\end{tabular}

various parameters are taken as follows: $\mathrm{V}_{\mathrm{F}}=0.74 \mathrm{~V} ; \mathrm{R}_{\mathrm{L}}=$ $0.01 \Omega ; \mathrm{R}_{\mathrm{S}}=0.027 \Omega ; \mathrm{R}_{\mathrm{D}}=0.0177 \Omega$. From the graph, it can be observed that the efficiency of the converter in presence of parasitic elements is varying between $95 \%$ and 95.65\%.

The switching loss is given in

$$
P_{S}=V_{i} I_{S}\left(t_{r}+t_{f}\right) f_{s} .
$$

The input power is given in

$$
P_{i}=\frac{M_{\mathrm{IDEAL}} V_{i} V_{o}}{R_{o}}
$$

The constants $A, B, C$, and $D$ are same as described above in Equation (11).

\section{Analysis of Voltage Stress and Current Stress}

4.1. Voltage Stress Analysis. The voltage stress across the three switches $S_{1}, S_{2}$, and $S_{3}$ during off state are given in Equations (17), (18), and (19), respectively.

$$
\begin{aligned}
& V_{\mathrm{SW} 1}=\frac{2 V_{i}+V_{o}}{4}, \\
& V_{\mathrm{SW} 2}=\frac{V_{o}}{2}, \\
& V_{\mathrm{SW} 3}=\frac{2 V_{i}-V_{o}}{4} .
\end{aligned}
$$

The voltage stress across the various diodes during reverse biased condition are given as follows:

$$
\begin{aligned}
& V_{D 1}=-V_{i}, \\
& V_{D 2}=V_{D 3}=V_{D 4}=\frac{-V_{o}}{2},
\end{aligned}
$$

where $V_{\mathrm{D} 1}, V_{\mathrm{D} 2}, V_{\mathrm{D} 3}$, and $V_{\mathrm{D} 4}$ are the voltages across the diodes $\mathrm{D}_{1}, \mathrm{D}_{2}, \mathrm{D}_{3}$, and $\mathrm{D}_{4}$, respectively, during the reverse biased condition.

4.2. Current Stress Analysis. The maximum current flowing through the various components of the proposed converter 
is determined by applying Kirchoff's Current Law (KCL) during various modes of operation. From Figures 3(a)$3(\mathrm{c})$, the current through the inductors $\mathrm{L}_{1}$ and $\mathrm{L}_{2}$ is derived as

$$
I_{L 1}=I_{L 2}=I_{o} \frac{2+d_{1}-d_{1}^{2}}{1-d_{2}}
$$

In the same way, the current through the switches $S_{1}, S_{2}$, and $\mathrm{S}_{3}$ are derived as

$$
I_{\mathrm{SW} 1}=I_{\mathrm{SW} 3}=I_{o} \frac{1+d_{1}}{1-d_{2}}, I_{\mathrm{SW} 2}=2 I_{o} \frac{1+d_{1}}{1-d_{2}} \text {. }
$$

Similarly, the current through the diodes $\mathrm{D}_{1}, \mathrm{D}_{2}, \mathrm{D}_{3}$, and $\mathrm{D}_{4}$ are derived as

$$
\begin{aligned}
& I_{D 1}=2 I_{o} \frac{1-d_{1}^{2}}{1-d_{2}}, \\
& I_{D 2}=I_{D 3}=I_{o} \frac{1+d_{1}}{1-d_{2}}, \\
& I_{D 4}=I_{o} \frac{1+d_{1}}{1-d_{2}} .
\end{aligned}
$$

\section{Design and Selection of Components}

5.1. Inductor Design. The minimum value of inductance for both the inductors $\mathrm{L}_{1}$ and $\mathrm{L}_{2}$ are determined using

$$
L_{1}=L_{2}=\frac{V_{i} d}{\Delta i_{L} f_{S}}
$$

where $\Delta i_{L}$ is the ripple current and is generally taken as $10 \%$ of the load current and $f_{S}$ is the switching frequency equal to $50 \mathrm{KHz}$.

5.2. Capacitor Design. The value of capacitors $C_{1}, C_{2}$, and $C_{o}$ are determined using

$$
C_{1}=C_{2}=C_{o}=\frac{P_{o}}{V_{o} \Delta V_{C} f_{S}},
$$

where $\Delta V_{C}$ is the ripple voltage and is usually assumed as $2 \%$ of the load voltage and $P_{o}$ is the load power.

\section{Performance Comparison}

This section analyses the comparative performance of the proposed converter and the other recent converters reported in the references, i.e., $[12,13,24-26]$, and the conventional boost and SEPIC converters. Detailed comparison of the proposed converter and the above converters is presented in Table 1 . The plot of duty ratio versus the voltage gain of these converters is shown in Figure 8. A fixed duty ratio of 0.4 is assumed as $d_{1}$ for the proposed converter. This plot clearly illustrates that the voltage gain attained by the proposed converter is higher compared to the other seven con-

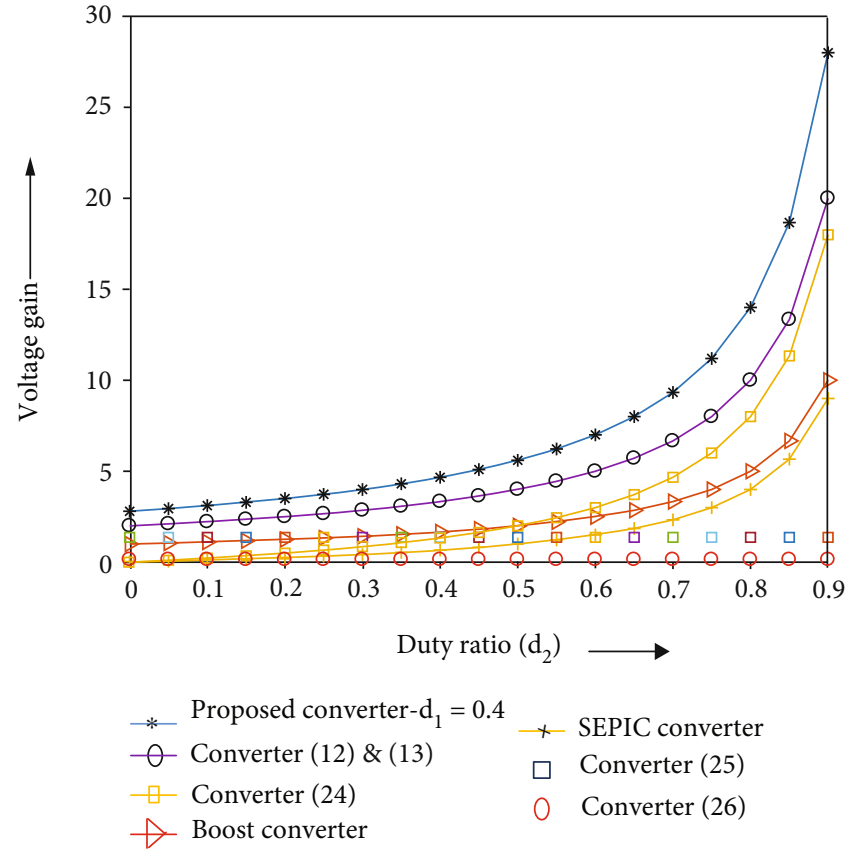

FIGURE 8: DC-voltage gain vs. duty ratio of the proposed converter and the compared converters.

TABLE 2: Simulation parameters.

\begin{tabular}{lc}
\hline Parameter & Value \\
\hline Input voltage & $48 \mathrm{~V}$ \\
Resistance of load & $75 \mathrm{ohms}$ \\
Frequency & $50 \mathrm{kHz}$ \\
Inductors $\mathrm{L}_{1}$ andL $_{2}$ & $0.5 \mathrm{mH}$ \\
Capacitors $\mathrm{C}_{1}, \mathrm{C}_{2}, \mathrm{C}_{o}$ & $250 \mu \mathrm{F}$ \\
Duty cycle for $\mathrm{S}_{1}$ and $\mathrm{S}_{3}$ & $40 \%$ \\
Duty cycle for $\mathrm{S}_{2}$ & $80 \%$ \\
\hline
\end{tabular}

verters. It can be observed that the proposed converter attains a gain of higher value at the lowest duty ratio $d_{2}$, whereas the other reported converters achieves the similar gain with higher duty ratio.

From Table 1, it is clearly noted that the switches in the proposed converter are subjected to a minimum voltage stress compared to the other converters reported. In conventional boost converter, the voltage stress across the switch is equal to the output voltage. So higher rating switch is needed. Even though the number of components used in the proposed converter seems to be slightly higher, it is of comparable value with the total component count in the recently reported converters. The increase in component count in the proposed converter is due to the use of crossconnected capacitor structure in the circuit for doubling the output voltage. The proposed converter shows a continuous input current which is most preferable for solar PV applications. Therefore, the proposed converter shows better performance than the reported converters. 

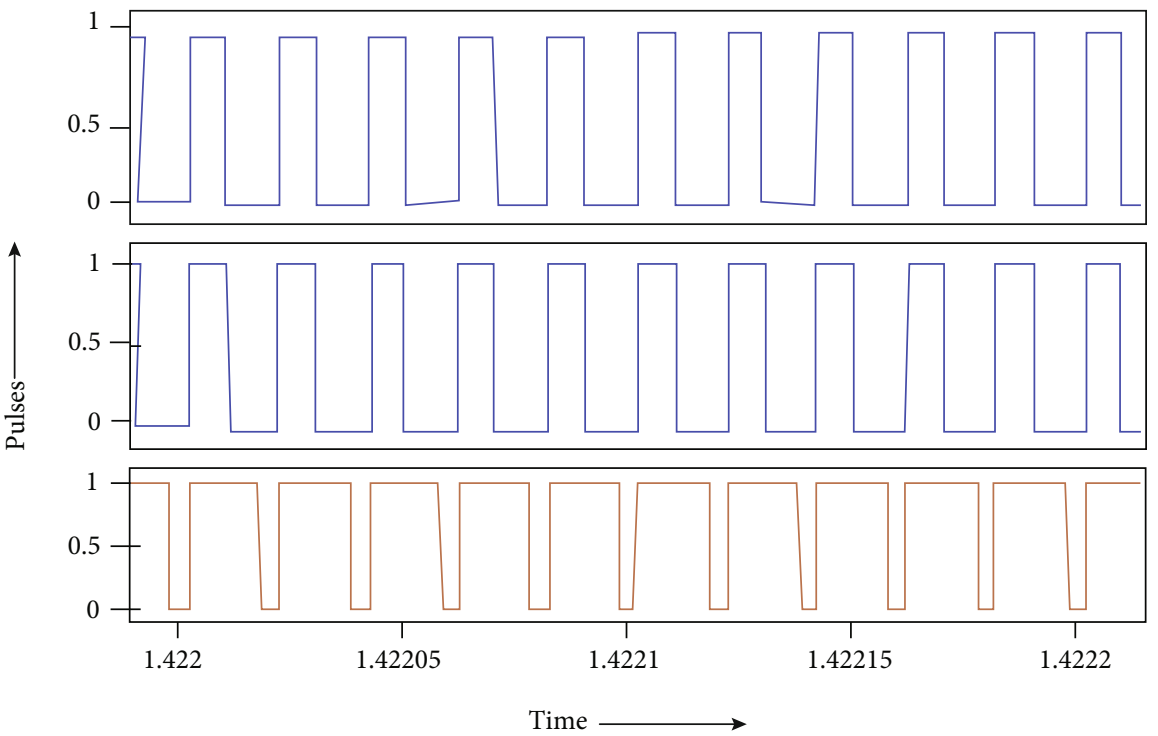

Figure 9: Switching pulses for $S_{1}, S_{3}$, and $S_{2}$.

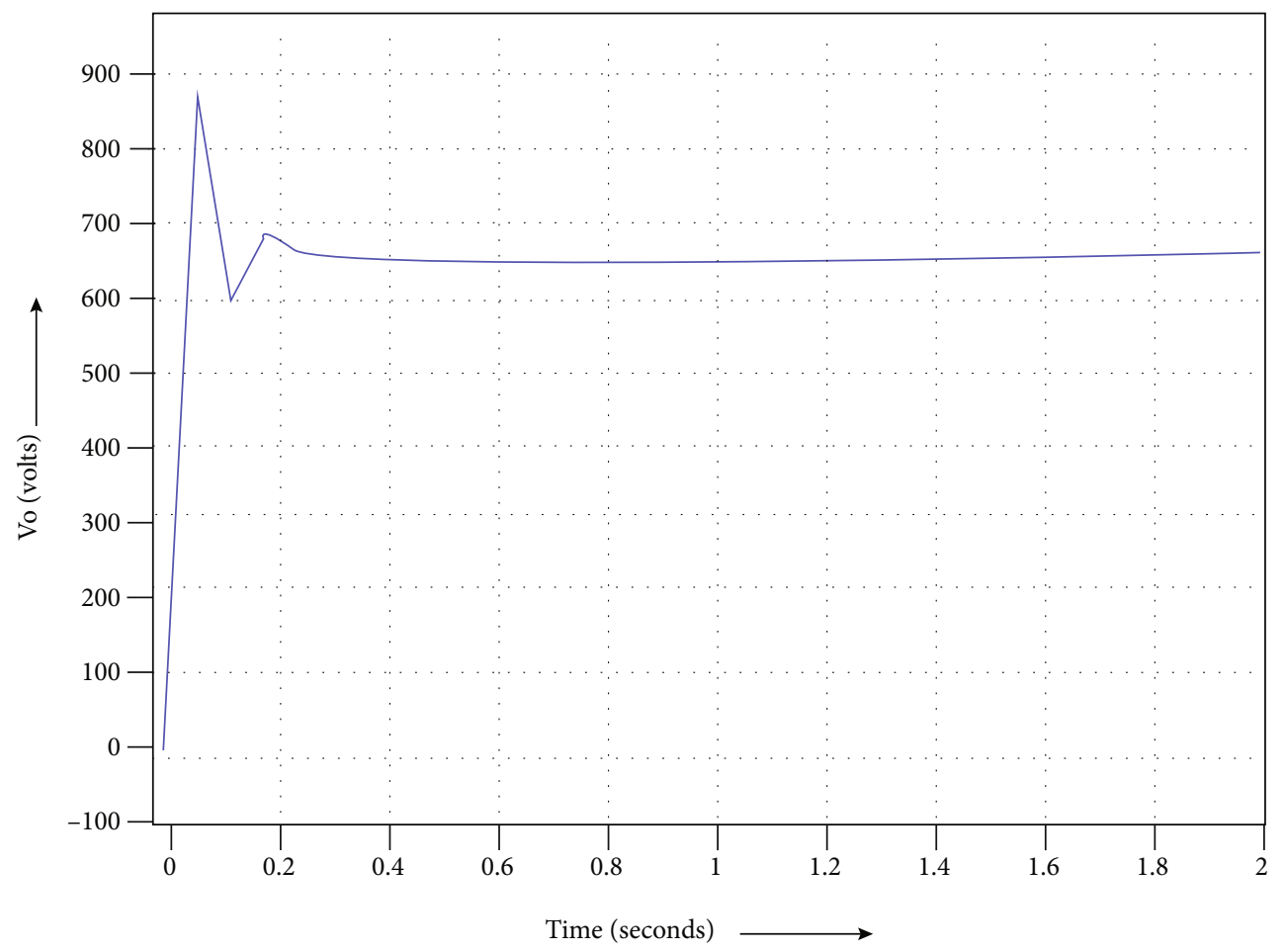

FIGURE 10: Output voltage of the proposed converter.

\section{Results and Discussion}

Simulation of the proposed converter has been carried out using MATLAB/Simulink platform. Converter parameter values taken for simulation are given in Table 2. Input voltage is taken as $48 \mathrm{~V}$ and the load resistance is $75 \mathrm{ohms}$. Various parameters of the proposed converter are measured, and the results are produced in this section. Waveforms of various parameters were observed and presented. Figure 9 shows the pulses applied to the switches. Duty ratio is taken as $40 \%\left(d_{1}\right)$ for switches $S_{1}$ and $S_{3}$ and is $80 \%\left(d_{2}\right)$ for $S_{2}$. Figure 10 shows the output voltage and is observed as $670.5 \mathrm{~V}$. Therefore, the gain of the proposed converter is 13.97 and is closely matches with its theoretical value.

Figure 11 shows the voltage stress appearing across the switches in the proposed converter. Figure 12 shows the voltage across the inductors $\mathrm{L}_{1}$ and $\mathrm{L}_{2}$. Both the inductors are charged to a voltage equal to input voltage of $48 \mathrm{~V}$ during mode 1 . In mode 2 , the voltage across the inductors is equal to half of the input voltage $24 \mathrm{~V}$. During mode 3 , when the 


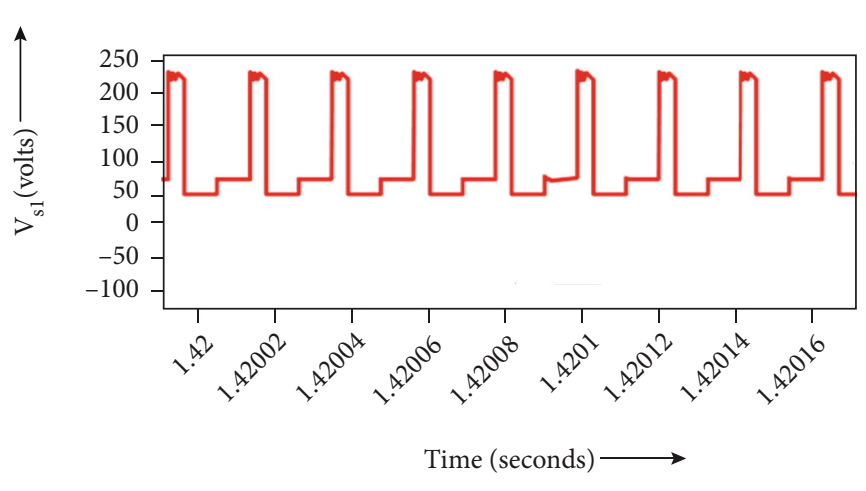

(a)

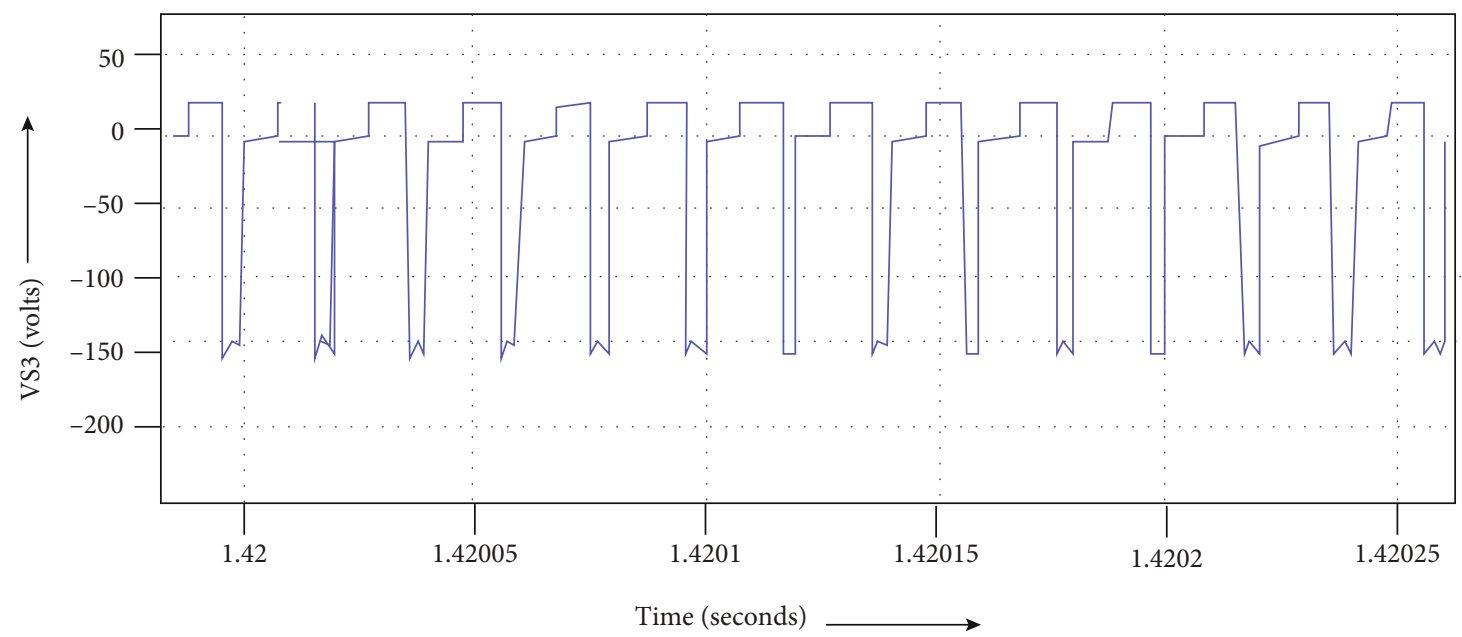

(c)

FIgURE 11: Voltage stress across the switches (a) $S_{1}$, (b) $S_{2}$, and (c) $S_{3}$.

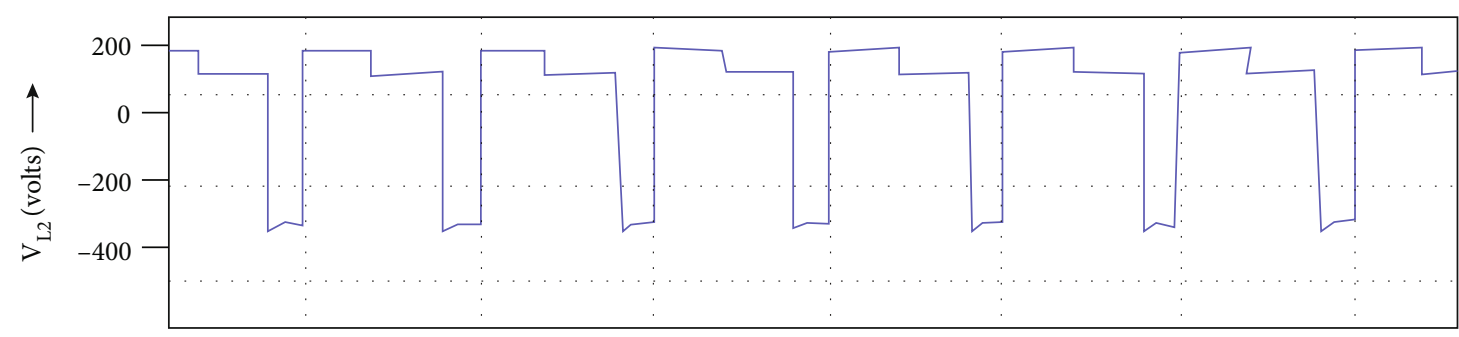

(a)

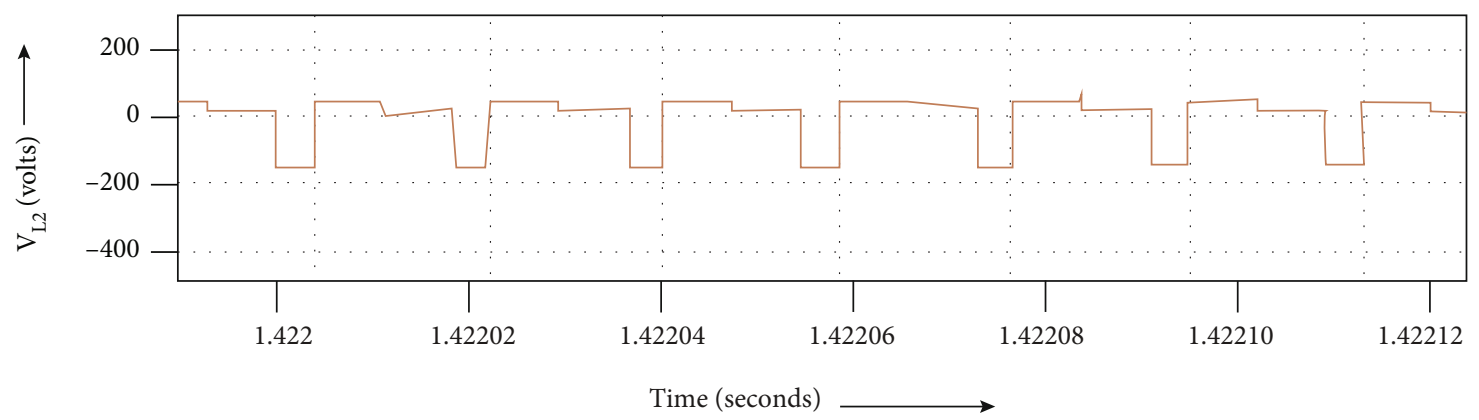

(b)

Figure 12: Voltage across the inductors (a) $\mathrm{L}_{1}$ and (b) $\mathrm{L}_{2}$. 
TABLE 3: Comparison of theoretical and simulation results.

\begin{tabular}{lcc}
\hline Parameters & $\begin{array}{c}\text { Theoretical } \\
\text { value }\end{array}$ & $\begin{array}{c}\text { Simulated } \\
\text { value }\end{array}$ \\
\hline Voltage gain & 14 & 13.97 \\
Output voltage & $670 \mathrm{~V}$ & $670 \mathrm{~V}$ \\
Voltage stress across switch $\mathrm{S}_{1}$ & $191.5 \mathrm{~V}$ & $191.7 \mathrm{~V}$ \\
Voltage stress across switch $\mathrm{S}_{2}$ & $335 \mathrm{~V}$ & $335.4 \mathrm{~V}$ \\
Voltage stress across switch $\mathrm{S}_{3}$ & $-143.5 \mathrm{~V}$ & $-143.6 \mathrm{~V}$ \\
\hline
\end{tabular}

switch $\mathrm{S}_{2}$ is turned off, the inductor discharges the stored energy, and the voltage across each inductor is observed as $-143.5 \mathrm{~V}$. Voltage stress across the switch $\mathrm{S}_{2}$ is measured as $335.4 \mathrm{~V}$ which is half of the output voltage $\left(V_{\mathrm{o}} / 2\right)$. Voltage stress across the switch $S_{1}$ is measured as $191.7 \mathrm{~V}$. Voltage stress across the switch $S_{3}$ is measured as $-143.6 \mathrm{~V}$. This validates the theoretical performance calculations.

Comparison of the simulated results and theoretical analysis with respect to various parameters is done and given in Table 3. From this, it is observed that both the results closely match which validate the performance of the proposed converter.

\section{Conclusions}

In this paper, a high step-up nonisolated DC-DC converter was proposed, analyzed, and validated through the simulation results. The proposed converter used a crossconnected capacitor structure which doubled the output voltage of the converter, and hence, the voltage gain is also doubled. The proposed converter was operated with $d_{1}=0.4$ and $d_{2}=0.8$ , and the voltage conversion ratio was theoretically calculated as 14. Also, the highest value of voltage across the switch is half of the output voltage, and therefore, the switching losses are reduced. Theoretical analysis was done in CCM, DCM, and BCM using the analytical waveforms. Comparative performance analysis was made with the recently reported converters and presented in the paper. Comparison of the voltage gain is done through the gain plot also. Comparative analysis shows that the proposed converter has a better performance than the other reported converters. The performance of the proposed converter was analyzed in presence of parasitic elements, and the expressions for output voltage and efficiency were derived. Finally, the simulation results and waveforms were presented to validate the proposed converter. Comparison of theoretical and simulation results is executed which validates the working of the proposed converter. Therefore, the proposed converter is best suitable for grid connected as well as for standalone solar PV applications.

\section{Data Availability}

Data will be provided on request.

\section{Conflicts of Interest}

The authors declare that they have no conflicts of interest.

\section{Acknowledgments}

The authors extend their sincere thanks to the management of Kumaraguru College of Technology for encouragement and support to execute this research work.

\section{References}

[1] Y. Zhang, H. Liu, M. Sumner, and C. Xia, "DC-DC boost converter with a wide input range and high voltage gain for fuel cell vehicles," IEEE Transactions on Power Electronics, vol. 34, no. 5, pp. 4100-4111, 2019.

[2] N. Elsayad, H. Moradisizkoohi, and O. A. Mohammed, "A single-switch transformerless DC-DC converter with universal input voltage for fuel cell vehicles: analysis and design," IEEE Transactions on vehicular technology, vol. 68, pp. 45374549, 2019.

[3] J. Leyva-Ramos, J. M. Lopez-Cruz, M. G. Ortiz-Lopez, and L. H. Diaz-Saldierna, "Switching regulator using a high stepup voltage converter for fuel-cell modules," IET Power Electronics, vol. 6, pp. 1626-1633, 2013.

[4] M. Yilmaz and P. T. Krein, "Review of battery charger topologies, charging power levels, and infrastructure for plug-in electric and hybrid vehicles," IEEE Transactions on Power Electronics, vol. 28, pp. 2151-2169, 2013.

[5] P. Ma, W. Liang, H. Chen, Y. Zhang, and X. Hu, "Interleaved high step-up boost converter," Journal of Power Electronics, vol. 19, pp. 665-675, 2019.

[6] A. Priyadarshi, P. K. Kar, and S. B. Karanki, "Switched capacitor based high gain DC-DC converter topology for multiple voltage conversion ratios with reduced output impedance," Journal of Power Electronics, vol. 19, pp. 676-690, 2019.

[7] B. Wu, S. Li, K. Smedley, and S. Singer, "A family of two-switch boosting switched-capacitor converters," IEEE Transactions on Power Electronics, vol. 30, pp. 5413-5424, 2015.

[8] G. Wu, X. Ruan, and Z. Ye, "Nonisolated high step-up DC-DC converters adopting switched-capacitor cell," IEEE Transactions on Industrial Electronics, vol. 62, pp. 383-393, 2015.

[9] M. Lakshmi and S. Hemamalini, "Nonisolated high gain DCDC converter for DC microgrids," IEEE Transactions on Industrial Electronics, vol. 65, pp. 1205-1212, 2018.

[10] H. Kang and H. Cha, "A new non isolated high-voltage-gain boost converter with inherent output voltage balancing," IEEE Transactions on Industrial Electronics, vol. 65, pp. 2189-2198, 2018.

[11] G. Yuanwei, Y. Chen, B. Zhang, D. Qiu, and F. Xie, "High stepup DC-DC converter with active switched $L C$-Network for photovoltaic systems," IEEE Transactions on Energy Conversion, vol. 34, no. 1, pp. 321-329, 2019.

[12] P. Wang, L. Zhou, Y. Zhang, J. Li, and M. Sumner, "Input-parallel output-series DC-DC boost converter with a wide input voltage range, for fuel cell vehicles," IEEE Transactions on Vehicular Technology, vol. 66, no. 9, pp. 7771-7781, 2017.

[13] J. C. Rosas-Caro, J. M. Ramirez, F. Z. Peng, and A. Valderrabano, "A DC-DC multilevel boost converter," IET Power Electronics, vol. 3, no. 1, pp. 129-137, 2010.

[14] F. M. Shahir, E. Babaei, and M. F. Farzad, "Voltage-lift technique based nonisolated boost DC-DC converter: analysis and design," IEEE Transactions on Power Electronics, vol. 33, pp. 5917-5926, 2018. 
[15] E. H. Ismail, M. A. Al-Saffar, A. J. Sabzali, and A. A. Fardoun, "A family of single-switch PWM converters with high step-up conversion ratio," IEEE Transactions on Circuits and Systems I: Regular Papers, vol. 55, pp. 1159-1171, 2008.

[16] J. Roy, Y. Xia, and R. Ayyanar, "High step-up transformerless inverter for AC module applications with active power decoupling," IEEE Transactions on Industrial Electronics, vol. 66, pp. 3891-3901, 2019.

[17] M. A. Salvador, T. B. Lazzarin, and R. F. Coelho, "High step-up DC-DC converter with active switched-inductor and passive switched-capacitor networks," IEEE Transactions on Industrial Electronics, vol. 65, pp. 5644-5654, 2018.

[18] E. Babaei, H. M. Maheri, M. Sabahi, and S. H. Hosseini, "Extendable nonisolated high gain DC-DC converter based on active-passive inductor cells," IEEE transactions on industrial electronics, vol. 65, no. 12, pp. 9478-9487, 2018.

[19] L. Zhou, F. Gao, and T. Xu, "Implementation of active NPC circuits in transformer-less single-phase inverter with low leakage current," IEEE Transactions on Industry Applications, vol. 53, pp. 5658-5667, 2017.

[20] J. C. Rosas-Caro, F. Mancilla-David, J. C. Mayo-Maldonado, J. M. Gonzalez-Lopez, H. L. Torres-Espinosa, and J. E. A. Valdez-Resendiz, "Transformer-less high-gain boost converter with input current ripple cancelation at a selectable duty cycle," IEEE Transactions on Industrial Electronics, vol. 60, pp. 4492-4499, 2013.

[21] L. C. Breazeale and R. Ayyanar, "A photovoltaic array transformer-less inverter with film capacitors and silicon carbide transistors," IEEE Transactions on Power Electronics, vol. 30, no. 3, pp. 1297-1305, 2015.

[22] M. P. Shreelakshmi, M. Das, and V. Agarwal, "Design and development of a novel high voltage gain, High-Efficiency bidirectional DC-DC converter for storage interface," IEEE Transactions on Industrial Electronics, vol. 66, no. 6, pp. 4490-4501, 2018.

[23] S. Hasanpour, A. Baghramian, and H. Mojallali, "A modified SEPIC-based high step-up DC-DC converter with quasiresonant operation for renewable energy applications," IEEE Transactions on Industrial Electronics, vol. 66, pp. 35393549, 2019.

[24] M. R. Banaei, H. Ardi, and A. Farakhor, "Analysis and implementation of a new single-switch buck-boost DC/DC converter,” IET Power Electronics, vol. 7, pp. 1906-1914, 2014.

[25] M. R. Banaei and S. G. Sani, "Analysis and implementation of a new SEPIC-based single-switch buck-boost DC-DC converter with continuous input current," IEEE Transactions on Power Electronics, vol. 33, no. 12, pp. 1031710325, 2018.

[26] N. Zhang, G. Zhang, K. W. See, and B. Zhang, "A singleswitch quadratic buck-boost converter with continuous input port current and continuous output port current," IEEE Transactions on Power Electronics, vol. 33, no. 5, pp. 41574166, 2018.

[27] D. Bao, A. Kumar, X. Pan, X. Xiong, A. R. Beig, and S. K. Singh, "Switched inductor double switch high gain DC-DC converter for renewable applications," IEEE Access, vol. 9, pp. 1425914270, 2021.
[28] M. Meraj, M. S. Bhaskar, B. P. Reddy, and A. Iqbal, "Non-isolated DC-DC power converter with high gain and inverting capability," IEEE Access, vol. 9, pp. 62084-62092, 2021.

[29] X. Hu, Y. Zhang, X. Liu, Z. Yu, T. He, and L. Mao, “A nonisolated step-up DC-AC converter with reduced leakage current for grid-connected photovoltaic systems," IEEE Access, vol. 8, pp. 71907-71916, 2020. 